Research Report No. 13/2010

\title{
Institutional Investors as Blockholders
}

Aviv Pichhadze

Follow this and additional works at: http://digitalcommons.osgoode.yorku.ca/clpe

\section{Recommended Citation}

Pichhadze, Aviv, "Institutional Investors as Blockholders" (2010). Comparative Research in Law \& Political Economy. Research Paper No. $13 / 2010$.

http://digitalcommons.osgoode.yorku.ca/clpe/81 


\title{
OSGOODE
}

OSGOODE HALL LAW SCHOOL

YOR K U N I VERS I T Y

\section{OSGOODE HALL LAW SCHOOL}

Comparative Research in Law \& Political Economy

\author{
RESEARCH PAPER SERIES
}

Research Paper No. 13/2010

\section{INSTITUTIONAL INVESTORS AS BLOCKHOLDERS}

Aviv Pichhadze

\section{Editors:}

Peer Zumbansen (Osgoode Hall Law School, Toronto, Director, Comparative Research in Law and Political Economy)

John W. Cioffi (University of California at Riverside)

Lisa Philipps (Osgoode Hall Law School, Associate Dean Research)

Nassim Nasser (Osgoode Hall Law School, Toronto,

Production Editors) 


\title{
Institutional Investors as Blockholders
}

\author{
By Aviv Pichhadze*
}

\author{
Presented at: \\ Corporate Governance in the Post, Post-World: The Public/Private Debate, The \\ Corporate Governance Symposium April 9-10 2010 \\ The New Zealand Governance Centre, The University of Auckland Business \\ School, New Zealand, April 9, 2010
}

\begin{abstract}
:
Pichhadze (2010) introduced the Market Oriented Blockholder Model (MOBM) as properly describing the ownership pattern in the American equity markets. Under the model, the emerging blockholder in the American equity markets is the institutional investor (II). This poses a challenge to the shareholder primacy literature, which argues that IIs (i) have interests that coincide with the interests of the shareholder body in the public firm, (ii) promote dispersed ownership, and (iii) crusade shareholder interests domestically and internationally. I show that (i) the position of IIs as blockholders creates a paradox for both the literature and the law, (ii) IIs have interests that do not coincide with those of other shareholders, and (iii) failure to recognize these observation vis-à-vis IIs or the MOBM may result in the introduction of a systemic risk into the financial system.

Key Words:

Corporate Governance; Ownership; Institutional Investors; Blockholders; Regulation; Capital Markets

JEL Classification:

K22, G23, G32, G34, G38

(C) 2010, Aviv Pichhadze. All rights reserved.
\end{abstract}

Contact Information:

Aviv Pichhadze

Osgoode Hall Law School

York University, Toronto, Canada

Mailing Address: 131 Oak Avenue, Richmond Hill, ON, L4C 6R6, Canada

Tel: +1.905.597.17.70

Email: avivpichhadze@osgoode.yorku.ca

*Osgoode Hall Law School, York University, Toronto, Canada. The article benefited from comments on previous versions by Amir Pichhadze and Ed Waitzer. I would like to extend my gratitude to Jacob A. R. ve YaZi whose support made this study possible. Any errors, omissions as well as the opinions expressed in this paper are, of course, my own. 


\title{
INSTITUTIONAL INVESTORS AS BLOCKHOLDERS
}

\section{By Aviv Pichhadze}

\begin{abstract}
Pichhadze (2010) introduced the Market Oriented Blockholder Model (MOBM) as properly describing the ownership pattern in the American equity markets. Under the model the emerging blockholder in the American equity markets is the institutional investor (II). This poses a challenge to the shareholder primacy literature, which argues that IIs (i) have interests that coincide with the interests of the shareholder body in the public firm, (ii) promote dispersed ownership, and (iii) crusade shareholder interests domestically and internationally. I show that (i) the position of IIs as blockholders creates a paradox for both the literature and the law, (ii) IIs have interests that do not coincide with those of other shareholders, and (iii) failure to recognize these observation vis-à-vis IIs or the MOBM may result in the introduction of a systemic risk into the financial system.
\end{abstract}

\section{KEY WORDS}

Corporate Governance; Ownership; Institutional Investors; Blockholders; Regulation; Capital Markets

\section{INTRODUCTION}

In describing the rise to prominence of the shareholder-oriented model of the corporate form, Hansmann and Kraakman note, inter alia, that this process involved the diffusion of public firm ownership and the rise to prominence of the institutional investors (IIs). ${ }^{1}$ In the context of IIs, Hansmann and Kraakman note that the interests of this shareholder group coincide "with those of public shareholders and ... [IIs] are prepared to articulate and defend those interests." ${ }^{2}$ In addition, they note that "[t]hese institutions not only give effective voice to shareholder interests, but promote in particular the interests of dispersed public shareholders rather than those of controlling shareholders or corporate insiders." ${ }^{3}$ Finally, in this context, they note that "the new activist shareholder-oriented institutions [i.e., IIs] are today acting increasingly on an international scale. ... We

\footnotetext{
${ }^{1}$ Henry Hansmann and Reinier Kraakman, "The End of History for Corporate Law” in Jeffrey N. Gordon and Mark J. Roe, ed., Convergence and Persistence in Corporate Governance (Cambridge, New York: Cambridge University Press, 2004) 33 at 48-49.

2 Ibid, at 49.

${ }^{3} \mathrm{Ibid}$, at 50. In this context, the authors note that a central tenet in the shareholder-oriented model that minority and non-controlling shareholders "should receive strong protection from exploitation at the hands of controlling shareholders” (ibid, at 42).
} 
now have not only a common ideology supporting shareholder-oriented corporate law, but also an organized interest group ... that is broad, diverse, and increasingly international ..."4

Accordingly, IIs seem to (i) have interests that coincide with the interests of the shareholder body in general in the public firm, (ii) promote dispersed ownership, and (iii) crusade shareholder interests internationally. Hence, they play an important role in corporate governance both domestically in the US and internationally. In this article, I examine these three propositions. I do this against the background of Pichhadze's Market Oriented Model (MOBM) that shows that the new blockholder in the American public equity markets is the II. ${ }^{5}$

This assessment is both timely and important as policymakers around the world are looking to fundamentally reform the global financial system and its various components. ${ }^{6}$ These reform initiatives are pursued with the view of correcting failures that led to the recent economic crisis in a coordinated and harmonized manner. The initiatives cover various levels and aspects of the financial system and include such things as transparency, risk management, supervision, regulation, and corporate governance. ${ }^{7}$ This article is concerned with the last area of proposed reforms - corporate governance. It is in this area that IIs play a significant role - a role that needs to be assessed for the purposes of promoting a stable and efficient global financial system.

The article is organized around three themes. First, in Part II, I show that the fact that IIs promote diffused ownership is a paradox given that they are the emerging blockholder in the equity markets, in general, and in large firms, in particular. Second, in Part III, I examine the extent to which II interests are aligned with those of other shareholders. More specifically, the article seeks to examine whether IIs behave in a manner that is not dissimilar to that of non-financial (e.g., retail or family) blockholders or controlling shareholders. Finally, in Part IV, the article will address some

${ }^{4}$ Ibid.

${ }^{5}$ Aviv Pichhadze, "The Nature of Corporate Ownership in the USA: The Trend Towards the Market Oriented Blockholder Model” (2010) 5:1 CMLJ 63. Given that the literature on corporate ownership structures does not make an explicit differentiation between the concentrated and the blockholder modes of ownership (and they are generally used interchangeably), for the sake of clarity, I divide the spectrum of public firm ownership into three clusters: concentrated ownership represents ownership levels in excess of 50.1\% of the firm's outstanding shares; blockholder ownership represents ownership levels between 5\% and 50\%; and dispersed ownership represents ownership level below the $5 \%$ levels. The choice of the $5 \%$ threshold is based on the disclosure filing requirements under s. 13(d), Securities and Exchange Act of 1934, 15 U.S.C.A. Ch. 2B, that requires, inter alia, disclosure of beneficial ownership of 5\% or more by any person of the outstanding shares of a firm's securities subject to Securities and Exchange Act. One should note, however, that while the above are used as a general guide, these lines of demarcation are fluid and are subject to change from one firm to another based on factors such as size of the firm and shareholdings of individual investors.

${ }^{66}$ See, e.g., OECD, Policy Framework for Effective and Efficient Financial Regulation: OECD Recommendation and Principles, OECD (December 3, 2009). Online: http://www.oecd.org/dataoecd/18/53/44187223.pdf (setting out key principles to guide policymakers on fundamental reforms).

7 OECD, “OECD sets out framework for overhaul of financial regulation” (December 4, 2009). Online: http://www.oecd.org/document/44/0,3343,en_2649_37467_44180524_1_1_1_1,00.html. 
regulatory implications, both domestically in the US and internationally, of the fact that IIs are the emergent blockholder. Part V provides some concluding remarks.

\section{INSTITUTIONAL INVESTORS AND THE PROMOTION OF DISPERSED OWN- ERSHIP - THE PARADOX}

As can be seen from above, IIs are said to shepherd the interests of dispersed owners and, in so doing, promote dispersed ownership as the appropriate form of public firm ownership in the equity markets. Yet, IIs are the emergent blockholder in the American equity markets holding over 66\% of the equity in these markets. ${ }^{8}$ Thus, we have a paradox between the stated purpose or objective of IIs in promoting dispersed ownership, on the one hand, and the reality of IIs as a blockholder, on the other. To understand how we arrived at this paradox, we need to examine the ownership trend in the American equity markets over the course of the $20^{\text {th }}$ century.

IIs in the US developed during the early years of the capital markets in that country and increased their exposure to equity investments during the 1950s. By the end of the 1950s the observed pattern in share ownership "was that individuals were shifting their capital from direct share ownership to institutional investments and bank deposits". ${ }^{9}$ By the end of the 1960s, interested observers were talking about the institutionalization of the American capital markets, ${ }^{10}$ a process that continues to this present day and sees the re-concentration of public corporate equity into the hands of IIs.

The process of the institutionalization of the American capital markets and the associated reconcentration of corporate ownership into the hands of institutional investors were an integral part of the trend towards the MOBM, as market forces were driving ownership patterns in the publicly listed firm towards the blockholder levels of ownership. Yet, since their initial stages in the early years of the American capital markets, IIs were treated as vehicles for the diffusion, rather than for the concentration, of ownership. ${ }^{11}$ In addition, some went as far as to proclaim that IIs "are the trustees for all shareholders. They establish the moral tone in Wall Street."12 A point of view that is both contradictory and forms the basis for the paradox.

\footnotetext{
${ }^{8}$ Carolyn K. Brancato and Stephan Rabimov, “The 2008 Institutonal Investment Report: Trends in Institutional Investor Assets and Equity Ownership of U.S. Corporations” (The Conference Board, 2008). Similarly, see James Hawley and Andrew Williams, "Universal Owners: Challenges and Opportunities” (2007) 15:3 Corp. Gov. 415, observing (at 415), “... most importantly, while there are many institutional investors, holdings are, in fact, concentrated in the hands of a relatively small number of the very largest institutional investors. For example, in the USA, the 100 largest fiduciary institutions hold fully 52 per cent of all publicly held equity” [emphasis in the original].

${ }^{9}$ Pichhadze, supra, note 5 , at 68.

${ }^{10}$ Ibid, at 73 .

${ }^{11}$ See, generally, ibid, 68-71, 73-79.

12 Joseph A. Livingston, The American Shareholder (New York: Collier Books, 1963) at 216.
} 
The MOBM is a hybrid ownership structure that features blockholder pattern of ownership that works with market mechanisms for the promotion of maintaining stability in the pattern of ownership (i.e., the maintenance of ownership equilibrium at the blockholder levels). The emergent blockholder in the US, as already noted, is the II. The synthesis of the blockholder mode of ownership with market mechanisms, such as takeovers, allows for the transformation of what Coffee described as the tradeoffs between the monitoring of corporate managers and the promotion of efficient and liquid markets resulting from the choice of the two polar ownership structures (i.e., concentrated and diffused, respectively) ${ }^{13}$ into complements ${ }^{14}$.

The MOBM is created through the need of market forces to arrive at an ownership equilibrium that affords both liquidity in the capital markets and monitoring of corporate management. The MOBM is facilitated by market mechanisms that assist in the promotion of such an equilibrium and its maintenance over time. Maintenance is required because the ownership equilibrium, once achieved, does not remain in a static state but, rather, it is a dynamic process that exhibits deviations from, and restoration to, the state. In this dynamic process, market mechanisms such as corporate control transactions (including private equity) have an important role in restoring the equilibrium state, once achieved, when disturbances or deviations from the equilibrium state occur.

As Pound observed in the context of leveraged buyout transactions, "[o]versight by entrepreneurial insurgent investors has been generated by two central (and related) features of U.S. capital markets: their fragmentation and their openness to innovation." 15 According to this view, when the ownership of a public firm becomes too fragmented such that (i) the firm experiences a reduction in the effective monitoring of the firm's management, and (ii) such reduced monitoring results in the introduction of inefficiencies to the firm, then (iii) market mechanisms such as takeover activity introduce into the firm improved monitoring and enhanced efficiency by, inter alia, concentrating, at least temporarily, the ownership of the firm.

Thus, advancement of the MOBM required two principal realizations by market forces. First, as industrial blockholders where diminishing from the large public corporation landscape during the early part of the $20^{\text {th }}$ century, market forces, in looking to fill the ownership gap, were reconcentrating ownership into the hands of fiduciaries that could take up the role of blockholders in these firms. ${ }^{16}$ Second, to achieve/maintain stability in this form of ownership, IIs, qua blockholders, realized that (in order to protect their investment, ensure increased returns on such investment,

\footnotetext{
13 John C. Coffee, Jr., “The Future as History: The Prospects for Global Convergence in Corporate Governance and Its Implications” (1999) 93 Nw. U. L. Rev. 641, at 648.

${ }^{14}$ Pichhadze, supra, note 5, at 83.

15 John Pound, "Raiders, Targets, and Politics: The History and Future of American Corporate Control”, (1992) 5 J. App. Corp. Finan. 6, at 8.

${ }^{16}$ According to Livingston (supra, note 12), IIs are as important as non-financial blockholders for the purpose of monitoring corporate managers (at 57 and 210).
} 
and ensure liquidity for such investments) they need to participate in the market for corporate control, as they have done since the 1980s. ${ }^{17}$

In order to facilitate their fuller participation in this type of activity, IIs successfully lobbied the legal system for amendments to rules, such as the proxy rules, when such rules prevented their fuller participation in the takeover arena. ${ }^{18}$ This activity was complemented by active investors who, as gap fillers in the corporate governance vacuum created as a result of fragmented ownership (i.e., through the concentration of ownership via takeover activity), realized the dual role and importance of institutional investors as both providers of capital and blockholders for the execution of deals.

Thus, the paradox in the American capital markets vis-à-vis IIs is that while they are viewed as promoting diffused ownership in both the US and elsewhere, they are in fact a blockholder in these markets. While paradoxical in the context of IIs, in the context of the MOBM, however, the fact that the MOBM is the emerging ownership pattern in the US shows us that market forces in that country are driving ownership patterns towards what can be said to be an optimal ownership structure that is also socially optimal.

Social optimality in the context of the corporation refers to the notion that the shareholders' representatives serve the shareholders' interest. ${ }^{19}$ One way of ensuring that this social welfare is met in the context of the corporation is through the monitoring of managers. The problem is that absent anyone owning sufficient stakes in the corporation, monitoring is left to market-mechanisms such as takeovers. ${ }^{20}$ Market forces and socio-economic realities, however, created a venue for the promotion of social optimality in the corporation. They have paved the way for the re-concentration of equity ownership into the hands of IIs, who have sufficient stake in the corporation and, therefore, an interest in monitoring corporate managers.

IIs, as blockholders, and takeovers are also two key features in the MOBM. They promote efficiency and liquidity in the capital markets while enabling the increased monitoring of corporate managers. In addition, given that a feature of the MOBM is the presence of a blockholder (whether an II or not), it points to the observation that market forces, in gravitating towards the MOBM, are attempting to reduce the sub-optimality created by the diffused ownership pattern of corporate ownership. $^{21}$

${ }^{1717}$ Pichhadze, supra, note 5, at 79-82.

${ }^{18} \mathrm{Ibid}$, at 79.

${ }^{19}$ See, generally, Sanford J. Grossman and Oliver D. Hart, “Takeover Bids, The Free-Rider Problem, and the Theory of the Corporation” (1980) 11 Bell J. Econ. 42.

${ }^{20}$ Ibid.

${ }^{21}$ As Bebchuk and Zingales observed, "the incidence of IPOs ... is larger in the United States than in other advanced economies ... While this large incidence of IPOs is generally taken to be a socially optimal outcome, our results suggest the possibility that this incidence is excessive" [emphasis added] (Lucian Arye Bebchuk and Luigi Zingales, "Ownership Structures and the Decision to Go Public: Private versus Social Optimality” in Randall Mork, ed., Con- 
Care, however, should be exercised in reading the above. While the MOBM may be structurally and, probably, socially optimal as an ownership structure (i.e., providing both enhanced monitoring and liquidity, on the one hand, and reducing the costs associated with the exercise of voice rights, on the other)), it does require a shift in regulatory thinking and approaches to corporate governance. This shift, and its nature, is not immediately available in the standard literature on corporate governance and, as such, there is no immediate "off-the-shelf” solution.

This is because the literature generally provides analysis of, and solutions to, cases involving the two polar extremes of corporate ownership (i.e., dispersed and concentrated). Whereas under the dispersed mode of ownership, the literature seeks to protect shareholders from managers, under the concentrated mode of ownership, the literature seeks to protect the shareholder class from the controlling shareholder. ${ }^{22}$ There are no solutions contemplated (or, indeed, discussed) to cases such as the MOBM. ${ }^{23}$

\section{INSTITUTIONAL INVESTORS AS BLOCKHOLDERS}

IIs are not a homogeneous group. They include pension funds, insurance companies, banks, and mutual funds to name a few. Despite this, they have generally come under criticism as owners of equity (in monitoring portfolio firms) and for failing to function as fiduciaries (on behalf of the investors that entrust them with their savings). For example, it was commented that "[h]istorically, millions of investors have acted like renters of corporate shareholdings rather than fractional owners of actual companies. Even worse, so do many of the mutual funds, retirement systems, and other fiduciaries to which citizen investors have entrusted their assets."24

In this section of the article, I examine the behaviour of IIs qua shareholders, using a number of examples, to see whether they behave in a manner that is distinct from other non-financial block-

centrate Corporate Ownership (Chicago: University of Chicago Press, 2000) 55, at 57). The assumption in the Bebchuk and Zingales analysis appears to be that going public translates into the assumption of diffused ownership structure for the corporation (i.e., atomistic share ownership).

22 See, e.g., Lucian A. Bebchuk \& Assaf Hamdani, “The Elusive Quest for Global Governance Standards” (2009) 157 U. Pa. L Rev. 1263.

${ }^{23}$ For example, Bebchuk and Hamdani note (in an analysis of corporate governance evaluation systems "for the numerous public companies around the world that can easily be classified as either [controlling shareholder companies] or [companies without controlling shareholders]" (ibid, at 1271-1272)), "[a]t the outset, we should acknowledge that some public companies lie in the gray area between those pure types because they have a dominant shareholder with substantial influence but not a compete lock on control. We leave it for another day the refinement of our analysis necessary for extending it to such companies" (at 1271). The omission from their analysis of those companies that fall in the "gray area" is unfortunate given that they form the bulk (as oppose to "some" as argued by Bebchuk and Hamdani) of the companies found in the US equity markets (see, e.g., Pichhadze, supra, note 5, at 71 and the references cited therein). In addition, their discussion is premised on the notion that blockholder ownership pattern are not conducive to market mechanisms such as takeovers.

${ }^{24}$ Stephen Davis, Jon Lukomnik, and David Pitt-Watson, The New Capitalists: How Citizen Investors are Reshaping the Corporate Agenda (Harvard University Press, 2006) at 66. 
holders. Prior to this, however, let us briefly look at the arguments claiming that IIs fail in their function as fiduciaries.

\section{A Institutional Investors as Fiduciaries - Some In- dustry Shortcoming}

Davis, Lukomnik and Pitt-Watson provide a number of reasons for IIs' failure in their role as fiduciaries. These criticisms relate to the fund industry in general and include (i) the manner in which fund managers get compensated, (ii) lack of economic incentive to monitor portfolio firms, (iii) the investment horizon of fund managers, and (iv) lack of member input and/or representation on corporate pension funds.

The first criticism results from the manner in which fund managers' compensation is calculated. In this context the authors note that because fund managers are paid on a percentage-of-assets basis (i.e., fees are based on the quantum of assets under management), fund managers have little (economic) incentive to monitor the assets under their care. ${ }^{25}$ That is, fund managers are compensated based on the size of assets under their management rather than on how well they engage with poorly performing firms in their portfolio.

Another reason is the investment horizon adopted by fund managers. The authors note that the fund industry rates fund managers' performance based on their relative performance over short time frames. These ratings translate themselves into bonus for individual managers and analysts. "The natural result is that they [i.e., fund managers and analysts] focus on lucrative short-term trading rather than on vigilant long-term owning.,26

A related reason for the failure of fiduciaries to act like owners according to the authors is the fact that the economic cost of monitoring does not result in a corresponding financial benefit to the individual fiduciary as all investors will share in the benefits resulting from the monitoring activities by the particular II. As such, fund managers prefer to beat market benchmarks (i.e., exhibit improved relative performance). ${ }^{27}$

A final criticism of IIs relates to pension funds. In this context Davis, Lukomnik and Pitt-Watson note that "many pension funds around the world operate with no representation at all from the very members they are supposed to benefit. Almost all corporate pension funds in the United States and Japan ... are run exclusively by company officials, with no such thing as a trustee board with seats for current or retired employees." 28 This, according to the authors, allows corporate managers to keep the pension fund captive (as fund managers will be careful to maintain their relations with the corporations) and, thus, fund managers will have reduced incentives to act as owners. In addition,

\footnotetext{
${ }^{25}$ See generally ibid, Chapter 4.

${ }^{26} \mathrm{Ibid}$, at 72.

${ }^{27}$ Ibid.

${ }^{28} \mathrm{Ibid}$, at 75 .
} 
the authors note that this practice allows corporate managers to hire fund managers that will not oppose management for fear of losing the company's fund business - i.e., fund managers do not exercise the ownership rights on behalf of policyholders.

\section{B Institutional Investors a $\mathrm{O}$ wners}

Despite some of the shortcomings of IIs at the industry level, IIs do perform and act as equity owners. It is worth examining their actions as shareholders in light of the fact that they are the emerging blockholders in the capital markets and the fact that they can potentially perform a valuable corporate governance function at both the domestic and international levels. In this section, IIs are treated as a homogeneous group for the sake of simplifying the discussion. While IIs, generally, are treated in the discussion below as a homogeneous group, shareholders are not. This is because shareholders have interests that are not common with other shareholders. ${ }^{29}$

The literature on corporate governance identifies several potential areas where a dominant shareholder can negatively impact the corporation and, as such, other shareholders. While a complete catalogue is beyond the scope of this article, I examine some of these areas to see if IIs have the capacity of behaving in a like manner. This will enable us to assess whether, on balance, IIs act as a dominant shareholder or a blockholder for the purposes of impacting corporate performance. This is important because the two types of shareholders (i.e., IIs, on the one hand, and blockholders, on the other) are generally treated differentially in the literature. In particular, I focus on (i) corporate boards and management catering to shareholder interests, (ii) ability to exercise formal power, and (iii) rent seeking and opportunism.

\section{(i) Board catering to shareholder interests}

In firms with a controlling shareholder there is the risk that management and the board of directors will follow the direction of the blockholder(s) while ignoring the interests of minority shareholders. ${ }^{30}$ In these situations, the agency problem results from the possible conflict or tension between the dominant shareholder, which is supported by the board and management who are under this shareholder's control, and the remaining shareholders. ${ }^{31}$

In the context of IIs, this raises the question of whether IIs receive (whether actual or perceived) special treatment from managements of boards. Recent developments in the capital markets point to the growing recognition by boards and managements of leading corporations of the important power of IIs qua blockholders. This has recently been observed by the American Bar Association Section of Business Law:

${ }^{29}$ See, e.g., Iman Anabtawi, “Some Scepticism about Increasing Shareholder Power” (2005-2006) 53 UCLA L. Rev. 561.

${ }^{30}$ Ronald J. Daniels and Randall Morck, “Canadian Corporate Governance: The Challenge” in Ronald J. Daniels and Randall Morck, eds., Corporate Decision-Making in Canada, Industry Canada Research Vol. V (Ottawa: University of Calgary Press, 1995) 3, at 12.

${ }^{31}$ Ibid. 
Boards also are more actively engaging in discussions with shareholders on a variety of governance related topics outside of the proxy proposal context, including nomination of directors, compensation matters, social and environmental issues, and the range of matters raised by shareholders during proxy season. Pfizer, UnitedHealth, and Home Depot, for example, initiated meetings with large institutional investors to discuss issues ranging from executive compensation to board composition. ${ }^{32}$ [Emphasis added]

Does this mean that Pfizer \& Co. Are serving the interests of large IIs at the expense of the remaining shareholder body? Not necessarily. But it does create a risk. This risk arises from the failure to appreciate two related observations. First, such activity by corporations appears to signal that corporations are listening to IIs in a manner that is not too dissimilar to listening to a non-financial blockholder (i.e., providing a preferential treatment to IIs over other shareholders). Similarly, Anabtawi and Stout note that IIs can, in some instances and contrary to conventional understanding, act in a manner similar to that of a controlling shareholder in influencing corporate conduct. ${ }^{33}$ Second, as Friday and Cram caution, "[d]irectors should ... be wary ... Activist shareholders are often motivated by their own economic, social or political agendas and do not necessarily speak for the silent majority of investors." 34

\section{(ii) Ability to exercise formal power}

It is generally accepted that dominant shareholders are likely to use formal powers to maximize the value of the share it owns. ${ }^{35}$ In a widely held firm the likelihood for this type of activity is less likely because "collective action and free-rider problems ... often prevent outside shareholders from effectively using whatever formal powers that they have to constrain and influence management." 36

While these assertions may be true in the polar cases of ownership structures (i.e., diffused and concentrated), Pichhadze, in his MOBM analysis, notes that IIs are using legal tools to influence corporations. ${ }^{37}$ For example, IIs are successfully using the proxy system and other shareholder

${ }^{32}$ Anonymous, "Report of the Task Force of the ABA Section of Business Law Corporate Governance Committee on Delineation of Governance Rules and Responsibilities” (2009) 65 Bus. Law. 107.

33 Iman Anabtawi and Lynn Stout, “Fiduciary Duties for Activist Shareholders” (2008) 60 Stan. L. Rev. 1255, at 12851286 (referring to the conflicted position of the California Public Employees' Retirement System (CalPERS) in the attempted removal of Safeway, Inc.'s CEO and Charir). This article also provides additional examples in which fiduciaries act in a manner that conflicts with the interests of other shareholders and the corporation.

${ }^{34}$ N. Kathleen Friday and Tracy Cram, “Top 10 Topics for Directors in 2008” (2008) 16:3 Corp. Gov. Advisor 11, at 12.

${ }^{35}$ Bebchuk and Hamdani, supra, note 21, at 1283. However, it has also been observed that "[d]ominant shareholders are perhaps less likely deliberately to push the firm toward non-value-maximizing activities ... After all, the dominant shareholder pays a high percentage of the cost himself” (Daniels and Morck, supra, note 29, at 13).

${ }^{36}$ Bebchuk and Hamdani, supra, note 21, at 1282.

${ }^{37}$ Pichhadze, supra, note 5, at 75-59 
rights mechanisms as well as successful lobbying of the SEC to introduce changes for the removal of barriers to enable fuller II participation in corporate affairs.

\section{(iii) Rent seeking and opportunism}

Shareholders are a group. As such, it allows them to benefit from the cooperative actions of group members. ${ }^{38}$ Such gains, however, are balanced against the negative impact of activities such as rent-seeking and opportunism carried out by some group members at the expense of others. This is because shareholders, as a heterogeneous group, have their own interests in addition to the common interests.

Rent seeking is "the socially costly attempt to obtain wealth transfers." 39 In firms with dominant shareholders, for example, Bebchuk and Hamdani note that the dominant shareholders can use selfdealing transactions with other entities affiliated with them to extract value. ${ }^{40}$ Anabtawi and Stout observe that this situation can also arise with IIs in countries such as the US (i.e., where ownership is assumed to be diffused), as in the case where IIs represent and promote their own interests. ${ }^{41}$ This relates to the risks associated with interplay between interest group politics and diffused ownership. The risk was highlighted as far back as 1925 where it was cautioned that interest groups (whether left- or right-wing), in advancing their interests, might use diffused ownership to their advantage. $^{42}$

A related type of rent seeking is the political rent seeking. Here, public choice theory provides that larger groups will be "more inclined to produce pressure in the pursuit of group-specific public goods." 43 An example of this can be found in the efforts of IIs to influence the composition of corporate boards. While the SEC's proposed rule ${ }^{44}$ is cushioned in language that is embracive of all shareholders in allowing them to participate in the process of nominating directors, the threshold

${ }^{38}$ In the context of corporate law, efforts by IIs during the 1990s to reduce restrictions on shareholder communications (see, e.g., ibid, at 81) may be thought of as an example of such efforts. Yet, even this example is subject to a qualification. This is because IIs were arguing in support of the proposed changes that they were long-term investors whereas the evidence was to the contrary (ibid).

${ }^{39}$ Anabtawi, supra, note 28, at 575.

${ }^{40}$ Bebchuk and Hamdani, supra, note 21, at 1283-1284.

${ }^{41}$ Anabtawi and Stout, supra, note 21, at 1285-1286. An editorial in the Wall Street Journal provides an additional example. The editorial argued that the California Public Employees' Retirement System (CalPERS) is attempting to impose corporate governance standards for their own pro-worker agendas on portfolio firms (Editorial, 'Conflicted in California', The Wall Street Journal, Eastern Edition, (11 May, 2004), A18).

42 S. McCune Lindsay, 'The Economic Revolution in the Ownership of Property in the United Sates', (1925) 11 Proceedings of the Academy of Political Science in the City of New York 3, Popular Ownership of Property: Its Newer Forms and Social Consequences, 1, 2-3.

${ }^{43}$ Frans van Winden, “Interest Group Behavior and Influence”, 118, at 120, in Charles Kershaw Rowley (ed.), Encyclopaedia of Public Choice, Volume 1 (Hingham, MA, USA: Kluwer Academic Publishers, 2003).

44 Facilitating Shareholder Director Nominations, 17 CFR Parts 200, 232, 240, 249 and 274 [Release Nos. 33904660089; IC-28765; File No. S7-10-09]. 
requirements are such that only a select group of shareholders can meet these requirements. ${ }^{45}$ This select group is composed mainly of IIs who, as a consequence of the size of their holdings, can meet the threshold requirements.

This type of rent seeking (i.e., influencing the representatives) also manifests itself at the level of the corporation and may provide for another example for the conflict of interest between IIs and other shareholders. For example, in instances where the II has cross-ownership in both the target and the bidding firms in cases of takeover transactions, the II can limit losses associated typically with the holdings of the bidding firm. ${ }^{46}$ Such crossholdings also translate to the reduction in the wealth of non-crossholding shareholders. This is because while the crossholding II seeks to optimize its return resulting from a transaction, it does so at the expense of the non-crossholding shareholder (or even a crossholding II with the "wrong" weight of stockholdings in either of the companies). The attempted takeover of Yahoo! by Microsoft in 2008 provides an illustration of this.

In connection with this proposed transaction, Microsoft made a $\$ 44.6$ billion bid for Yahoo!. It was reported that nearly 90\% of Yahoo's IIs had crossholdings in Microsoft, and most of Yahoo's top 20 IIs were also significant holders in Microsoft. ${ }^{47}$ "What's the implication? Any concession by Yahoo! to Microsoft's $\$ 44.6$ billion buyout has to benefit both holdings in order to be a net benefit to shareholders ... 'in theory an institutional shareholder may be likely to support a transaction, even one that is a poor deal for one side, provided the other side reaps a greater reward'. ${ }^{\text {, }}$, Thus, “[w]ith most of Yahoo!'s top investors having greater dollar exposure to Microsoft stock than Yahoo! Shares in their portfolio ... the most likely scenario is that 'we can expect shareholders who own both companies to pressure Yahoo directors to extract a material sweetener from Microsoft....."49

\section{(iv)Summation}

The above discussion and examples point to the shortcomings in Hansmann and Kraakman's observations made at the outset of this article vis-à-vis IIs. More specifically, the discussion showed that IIs interests do not coincide with those of other shareholders and, indeed, are often in conflict with those of the shareholder body as a whole. Moreover, the discussion pointed to the fact that IIs may behave in a manner akin to that of a dominant shareholder under the traditional analysis of diffused versus concentrated ownership structures in the scholarship. Finally, the observations shed doubt on the extent to which IIs provide voice to all shareholders.

\footnotetext{
${ }^{45}$ Pichhadze, supra, note 5, at 87-88.

${ }^{46}$ Gregor Matvos and Michael Ostrovsky, ‘Cross-Ownership, Returns, and Voting in Mergers' (2008) 89 J. Fin. Econ. 391. See also, Anabtawi and Stout, supra, note 32, at 1286-1288.

${ }^{47}$ Ray Tierman, “Report: Yahoo-Microsoft Investor Overlap Supports a Deal”, Barron’s, (February 15, 2008). Online: http://blogs.barrons.com/techtraderdaily/2008/02/15/report-yahoo-microsoft-investor-overlap-supports-a-deal/

${ }^{48}$ Ibid.

${ }^{49}$ Ibid.
} 


\section{REGULATORY IMPLICATIONS OF INSTITUTIONAL INVESTORS AS BLOCKHOLDERS}

The thrust of this article is that ownership patterns within a given economy matter from a regulatory standpoint for corporate governance initiatives. Observing changes in the landscape subject to this regulation is paramount if such initiatives are to have a positive (and, therefore, have social utility) rather than negative or neutral impact. This is the case whether we approach corporate governance from a domestic or international perspective. ${ }^{50}$ I will explore the significance of these statements in the context of the subject of this article - institutional investors.

It has been noted that "[i]n its broadest sense, corporate governance is concerned with holding the balance between economic and social goals and between individuals and communal goals. ... The aim is to align as nearly as possible the interests of individuals, of corporations, and of society."51 One way of achieving these goals is through the promotion of international corporate governance standards - standards that started as national codes and later became international guidelines. ${ }^{52}$ Key players in the promotion of these standards are IIs. ${ }^{53}$

IIs are instrumental in, and for, the introduction of codes of corporate governance. They produce their own codes of best corporate governance practices, which they try encourage their portfolio firms to adopt. IIs are also relied upon by governmental agencies for the adoption and introduction of codes recommended by these governmental agencies to institutional investors' portfolio firms. ${ }^{54}$ Thus, as Zumbansen observed, corporate governance regulation can be seen as "transnational and hybrid in nature" 55

This reliance on IIs poses a challenge to policy making. As was noted at the outset of this article, American IIs are credited for the promotion of shareholder-oriented model of corporate law around the world, which, inter alia, includes the promotion of dispersed ownership as the optimal model for corporate ownership. In addition, institutional investors are also credited with the reduction of

${ }^{50}$ See, e.g., Eddy Wymeersch, “Convergence or Divergence in Corporate Governance Patterns in Western Europe?” in Joseph A. McCahery, et al., eds., Corporate Governance Regimes: Convergence and Diversity, (Oxford; New York: Oxford University Press, 2002) 230, at 240. See also statement by Claessens noting, "[t]he nature of the corporate governance problems that countries face varies over time and between countries. One factor of importance is ownership structure ... [which affects] the legal and regulatory infrastructure necessary for good corporate governance ...” (in Stijn Claessens, “Corporate Governance and Development”, 1 Focus, October 2003, 11, online: http://www.gcgf.org/ifcext/cgf.nsf/Content/Focus_Notes).

51 Adrian Cadbury, “Forward” to Stijn Claessens, “Corporate Governance and Development”, 1 Focus, 2003, online: http://www.gcgf.org/ifcext/cgf.nsf/Content/Focus_Notes, p. vii.

${ }^{5}$ Ibid.

${ }^{53}$ Ibid, at v-vi.

${ }^{54}$ See, e.g., Chris A. Mallin, Corporate Governance (OUP, 2007) at 82-85.

${ }^{55}$ Peer Zumbansen, “Transnational Legal Pluralism” (January 26, 2010). CLPE Research Paper No. 01/2010, online: SSRN: http://ssrn.com/abstract=1542907, at 21. 
public distrust in large firms. ${ }^{56}$ Yet, as we have seen in Part II of this article, IIs are the emerging blockholder in the American equity markets. This paradox presents a potential challenge to policymaking. The potential challenge stems from the treatment of IIs in the corporate governance literature. This potential challenge also represents the point where economic analysis and legal analysis yield different results and, as such, depart from one another.

From an economic analysis perspective, whether we view them as blockholders or agents for the diffusion of ownership, IIs, as a powerful financial actor in the capital markets, offer the potential vehicle for the improvement of corporate governance practices. That is, IIs, as blockholders and transnational agents, possess the power to introduce the requisite change at both the national and international levels. Yet, this change poses a potential conflict due to the legal treatment accorded to IIs.

The conflict may be due to the source of the change. If the proposed change originates with the II, it does not automatically translate to mean that this proposed change is for the benefit of all the shareholders of the corporation, as the II's interests are not necessarily identical to those of other shareholders. If, on the other hand, the change originates from the State, the State may need to rely on the II to enforce compliance by portfolio firms with the proposed change. When the State does this, it does so based on the notion that the institutional investor is a powerful and influential blockholder in the markets.

While there may not be conflict per se in this process, it does lead us to question the fundamentals of corporate laws in countries such as the US, where the notion of dispersed ownership as being characteristic of the ownership pattern in that country is still upheld. This, therefore, leads to the conclusion that by necessity (as a result of the realization that a distortion is introduced into the legal system by viewing the American capital markets are properly characterised as fragmented) the regulatory framework in the US needs to be updated in order to give regulatory recognition to the fact that the ownership pattern in the US is the MOBM and that the blockholder in these markets is the II.

We can take this a little further. By failing to recognize that the MOBM represents the appropriate ownership pattern in the US and by continuing to promote policy initiatives that are premised on the assumption that the ownership pattern in the US is diffused, it is feasible that policymakers are

\footnotetext{
56 See, e.g., H. L. Stimson, “The Effects of Popular Ownership on Public Opinion” (1925) 11 Proceedings of the Academy of Political Science in the City of New York 3, Popular Ownership of Property: Its Newer Forms and Social Consequences, 134, 135-6. For a more recent expression of this idea, see, e.g., Stephen Davis, "Mobilizing ownership - the civil economy agenda”, 0.618..., Issue 6, (January 2006), p.8 (claiming that "[p]olicymakers around the world have a historic window of opportunity to shepherd a new policy of growth that transcends outmoded divides between at the anti-capitalism of the traditional left and the laissez-faire corporatism of the traditional right. The reason is the rise of mass ownership [referring to equity ownership via IIs]"). If that was the case, the reduction in distrust was apparently accompanied by (i) a retraction from laissez faire economic principles and (ii) increased governmental and political influences on commercial activities (see, e.g., H. C. Pell, Jr., "Consequences of Impersonal Ownership” (1925) 11 Proceedings of the Academy of Political Science in the City of New York 3, Popular Ownership of Property: Its Newer Forms and Social Consequences, 70).
} 
introducing a distortion into the regulatory system. This is because the two ownership patterns (i.e., diffused, on the one hand, and MOBM, on the other) give rise to different results and, as such, require different regulatory treatment. This is because in the case of diffused ownership the regulatory concern is the protection of shareholders from, for example, potential abuses by management, whereas in the case of blockholder ownership the concern is the protection of minority shareholders from, for example, abuses by the blockholder. Moreover, there is the possibility for the policymaker to introduce systemic risk into both the national and international financial systems. ${ }^{57}$

\section{CONCLUSION}

As the US markets gravitated towards a corporate ownership model, represented by the MOBM, that affords liquidity in the capital markets, on the one hand, and enhanced monitoring of corporate managers, on the other, market forces facilitated the concentration of ownership in the hands of a class of shareholders, the institutional investor, thereby transforming the American equity markets into a variant of the blockholder model.

From a policy perspective this trend and its resulting ownership model - the MOBM - are significant for the simple reason that failure to recognize it and adjust policy thinking in order to accommodate it (via changing regulatory attitudes and policies) may result in the introduction of a system risk into the financial system. This is because of the important impact that ownership structures have on corporate and securities laws and regulation.

The urgency of this accommodation is pressed for two fundamental reasons. First, given that IIs, as blockholders, do not behave in a manner that is predicted in the scholarship (i.e., representing and advancing shareholder interests), policymakers need to update the fundamentals of corporate and securities regulations in order for the regulations to fully reflect the realities created by IIs as blockholders. Second, the important role of IIs in the international arena also mandates such an update in order to reduce the introduction of systemic risk into the financial system (both global and domestic) resulting from the reliance on IIs for the promotion of improved corporate governance. In addition, while such regulatory rethinking is important in the context of developed nations, it is imperative in the context of developing nations that rely on the leadership of developed nations for the purposes of improving their corporate sectors and overall financial and economic viability and stability.

\footnotetext{
${ }^{57}$ On the connection between corporate governance and systemic risk, see, e.g., Gurria, "Opening remarks by Angel Gurria, OECD Secretary-General, at the ICGN annual conference”, Seol, 19 June, 2008, online: http://www.oecd.org/document/57/0,3343,en_2649_37439_40875513_1_1_1_1,00.html.
} 